\title{
Evidence that Calcineurin Is Rate-limiting for Primary Human Lymphocyte Activation
}

\author{
Thomas D. Batiuk, Lina Kung, and Philip F. Halloran \\ Department of Medicine, Division of Nephrology and Immunology, University of Alberta, Edmonton, Alberta AB T6G 2R8, Canada
}

\begin{abstract}
Cyclosporine (CsA) is both a clinical immunosuppressive drug and a probe to dissect intracellular signaling pathways. In vitro, CsA inhibits lymphocyte gene activation by inhibiting the phosphatase activity of calcineurin (CN). In clinical use, CsA treatment inhibits $50-75 \%$ of $\mathrm{CN}$ activity in circulating leukocytes. We modeled this degree of $\mathrm{CN}$ inhibition in primary human leukocytes in vitro in order to study the effect of partial $\mathrm{CN}$ inhibition on the downstream signaling events that lead to gene activation. In CsA-treated leukocytes stimulated by calcium ionophore, the degree of reduction in $\mathrm{CN}$ activity was accompanied by a similar degree of inhibition of each event tested: dephosphorylation of nuclear factor of activated $T$ cell proteins, nuclear DNA binding, activation of a transfected reporter gene construct, IFN- $\gamma$ and IL- 2 mRNA accumulation, and IFN- $\gamma$ production. Furthermore, the degree of $\mathrm{CN}$ inhibition was reflected by a similar degree of reduction in lymphocyte proliferation and IFN- $\gamma$ production in the allogeneic mixed lymphocyte cultures. These data support the conclusion that $\mathrm{CN}$ activity is rate-limiting for the activation of primary human $\mathrm{T}$ lymphocytes. Thus, the reduction of $\mathrm{CN}$ activity observed in CsA-treated patients is accompanied by a similar degree of reduction in lymphocyte gene activation, and accounts for the immunosuppression observed. (J. Clin. Invest. 1997. 100:1894-1901.) Key words: cyclosporine - calcineurin • lymphocytes $\bullet$ signal transduction $\bullet$ immunosuppression
\end{abstract}

\section{Introduction}

Cyclosporine $\mathrm{A}(\mathrm{CsA})^{1}$ is a cornerstone of maintenance immunosuppression in organ transplantation, and is used widely in

Address correspondence to Dr. Philip F. Halloran, Director, Division of Nephrology and Immunology, \#303, 8249-114 Street, Edmonton, AB T6G 2R8, Canada. Phone: 403-492-8880; FAX: 403-431-0461; E-mail: phil.halloran@ualberta.ca T.D. Batiuk's current address is Department of Medicine, Indiana University Medical Center, FH 115, 1120 South Drive, Indianapolis, IN 46202; tbatiuk@mdep.iupui.edu

Received for publication 7 February 1997 and accepted in revised form 14 August 1997.

1. Abbreviations used in this paper: CAT, chloramphenicol acetyltransferase; CI, confidence interval; CsA, cyclosporine; CN, calcineurin; $\mathrm{CyP}$, cyclophilin; EMSA, electrophoretic mobility shift assay; FK, FK-506; MLR, mixed lymphocyte reaction; NFAT, nuclear factor of activated T cells; PBL, peripheral blood leukocytes; PHS, pooled normal human serum.

J. Clin. Invest.

(C) The American Society for Clinical Investigation, Inc. 0021-9738/97/10/1894/08 \$2.00

Volume 100, Number 7, October 1997, 1894-1901

http://www.jci.org bone marrow transplantation and autoimmune disease. In vitro CsA suppresses lymphocyte activation by binding to cyclophilins (CyP), ubiquitous intracellular proteins with isomerase activity (1-3). The CsA-CyP complex binds to the calcium-regulated enzyme calcineurin $(\mathrm{CN})$, inhibiting its serine-threonine phosphatase activity (4-6). The immunosuppressive drug tacrolimus or FK-506 (FK) binds to an immunophilin, FK binding protein, creating a complex which similarly binds and inhibits $\mathrm{CN}(7,8)$. Activity of $\mathrm{CN}$ is necessary to activate key transcription factors. By inhibiting $\mathrm{CN}$ activation, CsA or FK prevent the dephosphorylation $(9,10)$ and subsequent nuclear translocation of the nuclear factor of activated $\mathrm{T}$ cells cytoplasmic proteins (NFATc), a family of transcription factors (10-12). Other transcription factors are also partially CN-dependent in T cells, such as AP-1 (13-15) and some members of the NF-кB/Rel family (16-19). These transcription factors govern the transcription of $\mathrm{T}$ lymphocyte activation genes, including many cytokine genes (IFN- $\gamma$, IL-2, GMCSF, and others) and genes controlling membrane molecules such as the CD40 ligand $(15,20,21)$. CsA or FK prevent the transcription of these genes $(4,22,23)$. Various observations support the essential role of $\mathrm{CN}$ in $\mathrm{T}$ lymphocyte activation: for example, the transfection of constitutively active $\mathrm{CN}$ makes cells relatively resistant to the effects of CsA (4), and a knockout which eliminates one isoform of CNA, CNA $\alpha$, reduces the immune responsiveness of the lymphocytes of the resulting mice (24).

While the qualitative role of $\mathrm{CN}$ inhibition in the effects of CsA on T lymphocyte activation is clear in vitro, the actual effect of $\mathrm{CN}$ inhibitors in vivo is less clear. The peripheral blood leukocytes (PBL) of CsA-treated transplant patients have reduced $\mathrm{CN}$ activity compared with healthy controls $(25,26)$. Even at peak CsA blood concentrations, complete inhibition of $\mathrm{CN}$ activity is uncommon $(27,28)$. Studies of CsA effect on $\mathrm{CN}$ activity and on gene expression in mice also revealed that CsA produced only partial inhibition except at very high concentrations (29). Thus, there is a discrepancy between the in vivo and the in vitro results: a given CsA concentration on a cell suspension in aqueous medium in vitro causes $\sim 10$-fold greater inhibition of $\mathrm{CN}$ activity compared with a similar blood concentration in vivo, or with the same concentration of cyclosporine in whole blood in vitro $(25,30)$. This discrepancy is due, at least in part, to the large number of binding sites for CsA in vivo, reducing the exposure of lymphocytes in vivo despite relatively higher CsA concentrations (31). Thus, modeling CsA effect by using the same concentrations in vitro (highly aqueous conditions) as those observed in vivo (with many CsA binding sites) may greatly overestimate its effect and recruit effects of the drug which are irrelevant to its in vivo actions. In spite of these considerations underscoring the importance of understanding $\mathrm{CN}$ inhibition and its immunologic consequences in quantitative terms, investigations of the quantitative relationships among CsA concentration, $\mathrm{CN}$ inhibition, and downstream effects have been limited (32). 
In these studies, we examined the effect of $\mathrm{CN}$ inhibition, to the degree measured in patients, on the downstream molecular events involved in cytokine gene activation and proliferation in freshly isolated human lymphocytes. We found that each degree of $\mathrm{CN}$ inhibition leads to a similar degree of inhibition of each of the downstream steps involved in both early cytokine gene activation and the longer term proliferation of antigen-stimulated cells. These data support the hypothesis that $\mathrm{CN}$ phosphatase activity is rate-limiting in human lymphocyte activation, and that the effect of CsA at concentrations which partially inhibit $\mathrm{CN}$ are parallel degree of inhibition of the dephosphorylation and translocation of NFATc, activation of cytokine transcription and production, and antigen-specific lymphocyte proliferation. These data support the view that the $\mathrm{CN}$ inhibitor CsA (and probably FK) is immunosuppressive because $\mathrm{CN}$ is rate-limiting in human $\mathrm{T}$ cell activation.

\section{Methods}

Cells and culture conditions. Samples of whole blood were obtained from healthy volunteers, and PBL were isolated by standard FicollHypaque gradient centrifugation. To reduce erythrocyte contamination, PBL were suspended in a solution containing $0.15 \mathrm{M} \mathrm{NH}_{4} \mathrm{Cl}, 10$ $\mathrm{mM} \mathrm{NaHCO}$, and $300 \mu \mathrm{M}$ EDTA, agitated for 3-5 min, and then washed twice with PBS. In cases of significant platelet contamination, $2.5 \mathrm{U}$ thrombin were added to the PBL suspension, and the resulting platelet aggregates were removed by gentle centrifugation. Enriched T lymphocyte populations were prepared using a negative selection column (Cellect Human T; Biotex Laboratories, Edmonton, Canada). T cell purity is reported to be $>95 \%$. Experiments were usually performed with PBL because the number of human T cells was limiting, and because $\mathrm{T}$ cell preparation may alter the $\mathrm{T}$ cells. In some experiments, human $\mathrm{T}$ cells were used, as indicated.

PBL were suspended at $5 \times 10^{6}$ cells $/ \mathrm{ml}$ and maintained in a humidified (95\% humidity) atmosphere at $37^{\circ} \mathrm{C}$ and $5 \% \mathrm{CO}_{2}$. Culture medium was RPMI 1640 (GIBCO BRL, Gaithersburg, MD), supplemented with $10 \%$ pooled normal human serum (PHS) (NABI, Miami, FL), $0.2 \mathrm{mM}$ glutamine (GIBCO BRL), and an antibiotic cocktail (GIBCO BRL) consisting of $250 \mu \mathrm{g} /$ liter amphotericin B, 100,000 U/liter penicillin $\mathrm{G}$, and $100 \mathrm{mg} /$ liter streptomycin sulfate.

Stimulation and inhibition. For short-term assays, PBL were stimulated with the calcium ionophore A23187 $5 \mu \mathrm{M}$ (ICN Biochemicals, Inc., Mississauga, Canada). Unstimulated control groups were treated with the A23187 solvent dimethyl sulfoxide at a final concentration of $0.05 \%$.

CsA, kindly supplied by Sandoz Canada Ltd. (Dorval, Quebec), was dissolved initially in 96\% ethanol and Tween 80 (Fisher Scientific Co., Fair Lawn, NJ), and a stock solution $(20 \mathrm{mg} / \mathrm{ml})$ was stored at $4^{\circ} \mathrm{C}$. Stock concentration was confirmed by measuring CsA by HPLC. Immediately before adding to culture, it was diluted to a desired concentration using medium. In all experiments, the concentration of CsA solvent was kept constant in all groups $\left(0.35 \times 10^{-3} \%\right.$ ethanol and $0.14 \times 10^{-3} \%$ Tween 80 ).

Calcineurin activity. CN activity was measured as described (25). In brief, PBL lysates were prepared and assayed for the ability to dephosphorylate a 19-amino acid peptide (DLDVPIPGRFDRRV$\left({ }^{32} \mathrm{P}\right)$ SVAAE). Background activity due to protein phosphatase $2 \mathrm{C}$, measured as ${ }^{32} \mathrm{P}$ released in the presence of CsA $1,000 \mu \mathrm{g} / \mathrm{l}$, was subtracted.

Western blotting. After treatment, whole cell lysates were prepared by suspending T lymphocytes in lysis buffer containing $5 \mathrm{mM}$ Tris- $\mathrm{HCl}, \mathrm{pH} 8.0,25 \mathrm{mM} \mathrm{NaCl}, 5 \%$ sodium dodecyl sulfate, $30 \mathrm{mM}$ sodium pyrophosphate, $5 \mathrm{mM}$ EDTA, $2 \mathrm{mM}$ PMSF, $250 \mu \mathrm{M}$ leupeptin, $100 \mathrm{mg} / \mathrm{l}$ aprotinin, and $5 \mathrm{mM}$ iodoacetamide. Cell suspensions were boiled for $5 \mathrm{~min}$, passed through a 26-gauge needle, boiled for $10 \mathrm{~min}$, then centrifuged for $40 \mathrm{~min}$. Proteins in the supernatant were quantitated (according to method of Bio-Rad Labs., Hercules, CA), separated by $6 \%$ SDS-PAGE, transferred to nitrocellulose, then probed for NFATC2 (formerly NFATp; NFAT nomenclature based on recommendations of Gene Data Bank on the World Wide Web at http:/gdwww.gdb.org/gdb-bin/lite/bin/genes) using a rabbit polyclonal antibody (Upstate Biotechnology Inc., Lake Placid, NY). This antibody was raised in rabbits against a 464-residue recombinant peptide, and reacts with mouse and human NFATC2 (10). Bands of interest were quantitated by densitometry.

Electrophoretic mobility shift assay (EMSA). After treatment of PBL, nuclear extracts were prepared by washing the PBL first with PBS, then with buffer A (10 mM Hepes, pH 7.8, $15 \mathrm{mM} \mathrm{KCl,} 2 \mathrm{mM}$ $\mathrm{MgCl}_{2}, 1 \mathrm{mM}$ EDTA, $0.1 \mathrm{mM}$ PMSF). The pellet was then suspended in buffer A plus NP-40 (0.2\%) and left on ice for five min. The cells were then centrifuged at 3,000 rpm for $3 \mathrm{~min}$, and the nuclear pellet was resuspended in $315 \mu$ l of buffer B $(50 \mathrm{mM} \mathrm{KCl}, 0.1 \mathrm{mM}$ EDTA, 1 $\mathrm{mM}$ DTT, $0.1 \mathrm{mM}$ PMSF, $10 \% \mathrm{vol} / \mathrm{vol}$ glycerol). The proteins were precipitated with $15 \mu \mathrm{l} 3 \mathrm{M} \mathrm{NH}_{4} \mathrm{SO}_{4}$, incubated with agitation on ice for $30 \mathrm{~min}$, then spun at $10,000 \mathrm{~g}$ for $20 \mathrm{~min}$. An equal volume of $3 \mathrm{M}$ $\mathrm{NH}_{4} \mathrm{SO}_{4}$ was added to the supernatant, and the mixture was incubated on ice for $20 \mathrm{~min}$, followed by centrifugation at 13,000 rpm for $30 \mathrm{~min}$. The pellet was suspended in buffer B, and protein concentrations were measured.

Complementary double-stranded oligonucleotides were synthesized using PCR-Mate ${ }^{\circledR}$ (Applied Biosystems, Inc., Foster City, CA). The sequence generated is the $\mathrm{P} 2$ sequence identified by Campbell et al. (33) as an NFAT binding site in the human IFN- $\gamma$ promoter. The sequence was 5' GATCTAAAATTTCCAGTCCTTGA $3^{\prime}$. The oligo probe was radiolabeled with ${ }^{32} \mathrm{P}$ using Klenow to fill in the ends. Competitors included Mutant P2, 5' GGGAGGTACAAAATCGACGCCAGTCCTTGAATCCTGTGAA 3', IL-4 P site, 5' GATCTGTGACTGACAATCTGGTGTAAGAAAATTTCCAATGTA 3' (33a).

Labeled probe $(\sim 25,000 \mathrm{cpm})$ was added to the binding reaction, and $12 \mu \mathrm{g}$ of nuclear extract was incubated with binding buffer containing $10 \mathrm{mM}$ Tris-HCl, $\mathrm{pH} 7.5,1 \mathrm{mM}$ EDTA, $1 \mathrm{mM}$ DTT, $12.5 \%$ glycerol, $50 \mathrm{mM} \mathrm{KCl}$, and $0.1 \%$ Triton-X 100 . Poly dIdC $(2 \mu \mathrm{g})$ and $5 \mu \mathrm{g}$ BSA were added to each sample. Samples were incubated at room temperature for 30 min before running on a $6 \%$ TBE gel for 90 min. The gel was dried and autoradiographed. For competition/supershift experiments, 100-200-fold excess of unlabeled competitor oligos were added to the extracts and incubated for $10 \mathrm{~min}$ at room temperature before the addition of labeled probe. Characterization of the binding protein(s) was carried out by determining the effect of incubating the protein-DNA complex with anti-NFAT antibodies. These were added to the binding buffer for $4 \mathrm{~h}$ at $4^{\circ} \mathrm{C}$ before running the gel. The antibodies included an anti-mouse anti-NFATC2 polyclonal antibody (see Western blotting, above) that was raised in rabbits against a 464-residue recombinant peptide, and is cross-reactive with human NFATC2 (10). The other antibody (a generous gift from Dr. G. Crabtree, Stanford University, CA) was the antihuman antiNFATC1 mAb G1-D10 raised against a 134-residue peptide that lies just amino-terminal to the Rel homology domain.

Transient transfection and chloramphenicol acetyltransferase (CAT) assay. Transient transfection experiments were performed with PBLblasts that were prepared by culturing freshly isolated PBL in medium (with $20 \%$ PHS) with $1 \%$ PHA (GIBCO BRL) for $72 \mathrm{~h}$. Blasts were suspended at $20 \times 10^{6}$ cells $/ \mathrm{ml}$ with $80 \mu \mathrm{g}$ DNA, comprising a reporter gene construct containing three repeats of the CsA-sensitive P2 sites found in the human IFN- $\gamma$ gene (33) upstream of the pCATPR plasmid (Promega Corp., Madison, WI). This plasmid has the SV40 promoter and the CAT gene. After $10 \mathrm{~min}$ at room temperature, the blast/DNA mix was electroporated (Bio-Rad Labs.) at $0.250 \mathrm{~V}$ and $960 \mu \mathrm{F}$ in $250-400 \mu \mathrm{l}$ aliquots and then left at room temperature for another $10 \mathrm{~min}$, after which the aliquots were mixed, suspended at $10^{6} \mathrm{cells} / \mathrm{ml}$, and incubated at $37^{\circ} \mathrm{C}$ for $1 \mathrm{~h}$ before addition of CsA. $10 \mathrm{~min}$ after addition of CsA, cells were stimulated with A $231875 \mu \mathrm{M}$ for $48 \mathrm{~h}$.

To obtain cell extracts, cells were washed twice in PBS, once in TEN (40 mM Tris-HCl, pH 7.5, 1 mM EDTA pH 8.0, 150 mM NaCl), 
and resuspended in $100 \mu \mathrm{l} 0.25 \mathrm{M}$ Tris- $\mathrm{HCl}, \mathrm{pH}$ 7.5. The cells were then lysed by three cycles of freeze-thaw and centrifuged at $10,000 \mathrm{~g}$ for $5 \mathrm{~min}$. The supernatant was removed and heated to $65^{\circ} \mathrm{C}$ for 10 min. CAT activity was assayed by combining $75 \mu \mathrm{l}$ of the supernatant, $4 \mu \mathrm{l}{ }^{14} \mathrm{C}$-chloramphenicol (Amersham Corp., Arlington Heights, IL), $4 \mu \mathrm{l} 5 \mathrm{mg} / \mathrm{ml} \mathrm{N}$-butyryl CoA (Sigma Chemical Co.), and $42 \mu \mathrm{l} 2 \mathrm{M}$ Tris- $\mathrm{HCl}, \mathrm{pH} 7.5$. After incubation at $37^{\circ} \mathrm{C}$ for $24 \mathrm{~h}, 300 \mu \mathrm{l}$ xylene was added, and the samples were vigorously mixed. After 3 min centrifugation, the top layer was removed, and $100 \mu \mathrm{l}$ Tris- $\mathrm{HCl}$ was added. The mixture was vortexed and recentrifuged, and the top layer was counted in a liquid scintillation counter.

RNA extraction and Northern blotting. After stimulation, cells were harvested, washed with PBS, and total cellular RNA was extracted as described $(34,35)$. RNA was electrophoresed on $1.5 \%$ agarose/2.2 M formaldehyde gel using $15 \mathrm{mg}$ RNA per well and transferred on nitrocellulose membrane for hybridization with ${ }^{32} \mathrm{P}$-labeled cDNA probes. Probing was performed using a standard procedure (36). Quantitation of ${ }^{32} \mathrm{P}$-labeled Northern blots and EMSAs was performed using a Bio-Imager (BASS 1000; Fuji Photo Film Co., Tokyo, Japan).

Measurement of IFN- $\gamma$. IFN- $\gamma$ in tissue culture supernatants was assessed using an IFN- $\gamma$ ELISA kit (Biosource International, Camarillo, CA, or Endogen, Inc., Woburn, MA).

Mixed lymphocyte reaction (MLR). MLR was performed using $5 \times$ $10^{4}$ stimulator and $5 \times 10^{4}$ responder PBL in a total of $0.2 \mathrm{ml}$ medium in sterile 96-well plates. Stimulator cells were irradiated with 2,000 rads before addition to culture. 16-24 h before harvesting, $2 \mathrm{mCi}$ $\left[{ }^{3} \mathrm{H}\right]$ thymidine was added to each well. Cells were harvested, washed, counted, and added to scintillation vials with $4 \mathrm{ml}$ of scintillation fluid, and the cpm was counted.

Statistical analysis. Curve fitting and statistical analyses were performed as described, using Prism software (GraphPAD Software for Science, San Diego, CA).

\section{Results}

We showed previously that PBL freshly removed from the blood of CsA-treated patients have $\sim 50 \%$ reduction of their $\mathrm{CN}$ activity at trough CsA blood levels (25). Moreover, $\mathrm{CN}$ inhibition rises and falls with the rise and fall of CsA blood levels, rising from $50 \%$ at trough CsA levels $12 \mathrm{~h}$ after dose to $75 \%$ for a brief time at peak CsA concentrations, then declining to baseline (reference 27, and Batiuk, T.D., F. Pazderka, and P.F. Halloran, manuscript submitted for publication). These clinical observations prompted us to explore the effects of $50-75 \% \mathrm{CN}$ inhibition in PBL in vitro (Fig. 1). We established CsA concentrations in aqueous medium which partially inhibit $\mathrm{CN}$ to approximate the state of PBL in CsA-treated humans. For four individual experiments, the mean $\mathrm{IC}_{50}$ was 10 $\mu \mathrm{g} /$ liter (95\% CI, 9-14 $\mu \mathrm{g} /$ liter); individual $\mathrm{IC}_{50}$ s ranged from 8 to $23 \mu \mathrm{g} / \mathrm{liter}$. The data fit a sigmoidal dose response curve with a goodness of fit of $r^{2}=0.9995$. Similar results were found with purified T cells (data not shown).

Having established the appropriate range of in vitro CsA to mimic the degree of partial $\mathrm{CN}$ inhibition obtained clinically, we investigated the consequences of partial $\mathrm{CN}$ inhibition on a series of steps involved in cytokine activation in T lymphocytes or whole PBL that occur subsequent to $\mathrm{CN}$ activation: NFAT activation and translocation, activation-induced DNA binding of nuclear proteins to a site in the IFN- $\gamma$ promoter, activation of a CAT construct in transfected cells via a sequence in the IFN- $\gamma$ promoter, IFN- $\gamma$ mRNA induction and IFN- $\gamma$ cytokine secretion during short term stimulation, and proliferation of $\mathrm{PBL}$ and IFN- $\gamma$ production in cells responding during MLR.

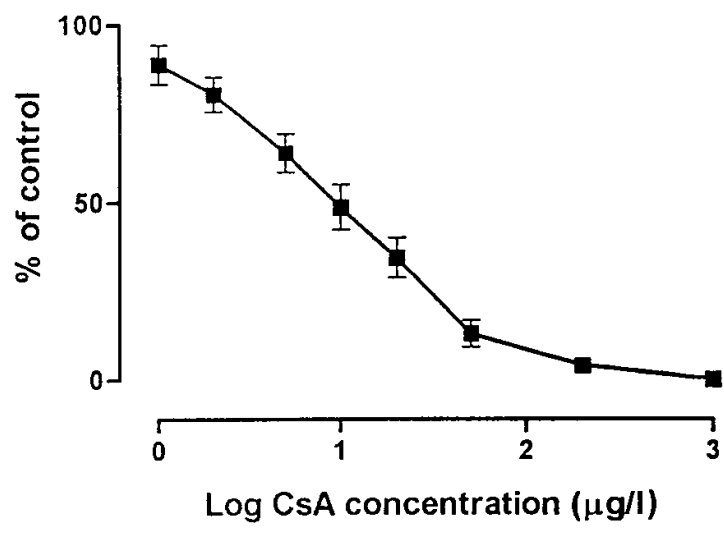

Figure 1. In vitro CsA inhibition of PBL CN activity. PBL were exposed to CsA at concentrations of 0 (solvent), 1, 2, 5, 10, 20, 50, 200, and $1,000 \mu \mathrm{g} /$ liter. PBL were lysed, and $\mathrm{CN}$ activity was measured. The results show the mean $\pm \mathrm{SD}$ of four individual experiments. The mean $\mathrm{IC}_{50}$ was $10 \mu \mathrm{g} /$ liter (95\% CI, 9-14 $\mu \mathrm{g} /$ liter); individual $\mathrm{IC}_{50} \mathrm{~S}$ ranged from 8 to $23 \mu \mathrm{g} /$ liter.

Activation of NFATc. CN activation leads to dephosphorylation of multiple serines in NFATc, accompanied by a reduction in the apparent molecular weight of NFATc $(9,10)$. To examine this step, T cells were exposed to CsA for $30 \mathrm{~min}$, stimulated with A23187 $5 \mu \mathrm{M}$ for $5 \mathrm{~min}$, and immunoblotted with a polyclonal anti-NFATC2 antibody (Fig. 2). Extracts from unstimulated cells (lane 1) showed a sharp band at $\sim 140$ $\mathrm{kD}$. In the absence of CsA, stimulation resulted in the disappearance of this band and the appearance of a new, less distinct band at $\sim 120 \mathrm{kD}$. These bands are consistent in size with phosphorylated and dephosphorylated forms of NFATC2, respectively $(9,10)$. The bands were quantitated using densitometry. With increasing concentrations of CsA, the loss of the upper band was inhibited, and the ratio of the upper band (phosphorylated NFATC2) to the sum of both bands increased, indicating that dephosphorylation was inhibited by $\mathrm{CsA}$ in a concentration-dependent manner, with an $\mathrm{IC}_{50}$ of 20 $\mu \mathrm{g} /$ liter (95\% CI, 15-26 $\mu \mathrm{g} /$ liter). Thus, the $\mathrm{IC}_{50}$ was in the same range as that for CsA inhibition of $\mathrm{CN}$.

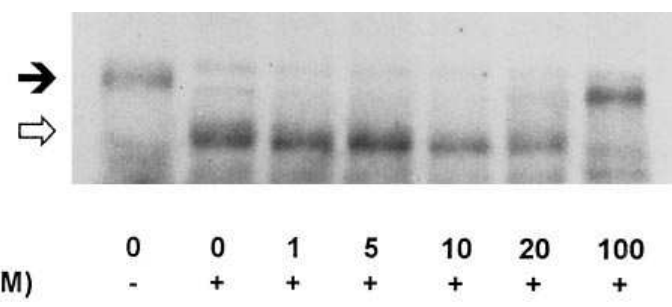

Figure 2. Anti-NFATC2 immunoblot of whole cell extracts from T lymphocytes stimulated for $5 \mathrm{~min}$ by A23187. T lymphocytes were purified from freshly isolated human PBL, and exposed to CsA for 30 min before stimulation with A23187 $5 \mu \mathrm{M}$ (lanes 2-7) for $5 \mathrm{~min}$. Whole cell extracts were prepared, and for each group, $200 \mu \mathrm{g}$ protein was separated by $6 \%$ SDS-PAGE, transferred to nitrocellulose, and immunoblotted with an anti-NFATC2 polyclonal antibody. Upper band (black arrow) is at $\sim 140 \mathrm{kD}$, and lower band (white arrow) is at $\sim 120 \mathrm{kD}$. 


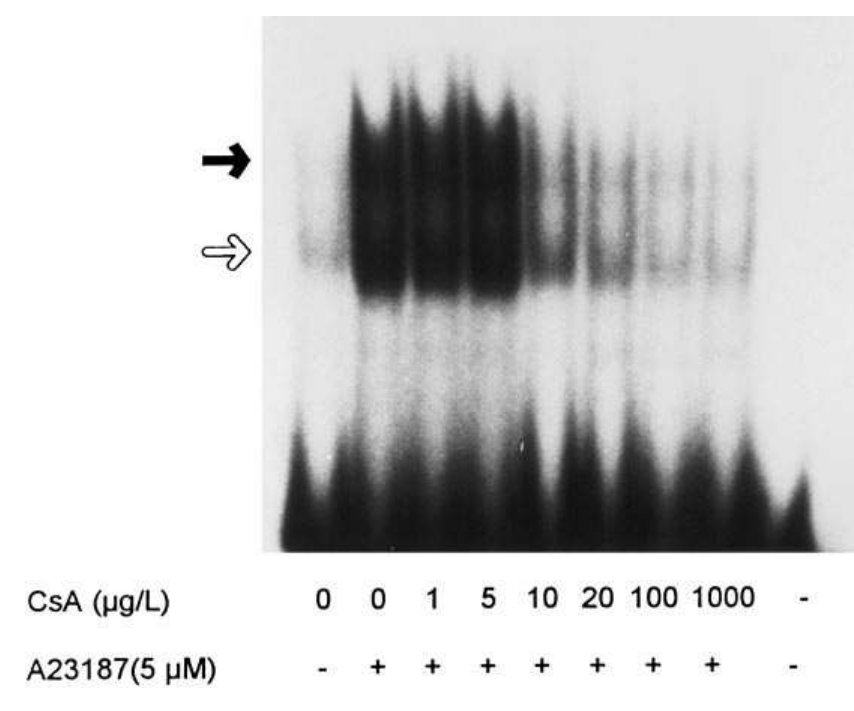

Figure 3. Effect of in vitro CsA on binding activity of nuclear proteins from stimulated PBL to DNA. PBL were treated with CsA, as indicated, for $30 \mathrm{~min}$ before stimulation with A23187 $5 \mu \mathrm{M}$ for $5 \mathrm{~min}$. Nuclear proteins were isolated, quantitated, and for each group, equal amounts of protein were incubated with the ${ }^{32} \mathrm{P}$-labeled DNA sequence corresponding to the P2 NFAT-binding site in the human IFN- $\gamma$ promoter (33). The mixtures were then run through a $6 \%$ TBE gel, dried, and autoradiographed.

The anti-NFATC2 antibody was raised in rabbits against murine epitopes. When similar experiments were performed in murine spleen cells, the $\mathrm{IC}_{50} \mathrm{~s}$ ranged between $7 \mu \mathrm{g} /$ liter for a crude splenocyte preparation and $18 \mu \mathrm{g} / \mathrm{liter}$ for purified splenic T cells (our unpublished data). Western blots of PBL preparations not enriched for $\mathrm{T}$ lymphocytes were too insensitive to detect these changes.

$D N A$ binding activity. We then examined the effect of CsA on the DNA binding characteristics of nuclear proteins from stimulated PBL. Nuclear proteins from control and stimulated PBL were incubated with a ${ }^{32} \mathrm{P}$-labeled DNA probe with a sequence corresponding to the NFAT-binding P2 site from the human IFN- $\gamma$ gene promoter (33). This mixture was then electrophoresed through a $6 \%$ TBE gel, dried, and autoradiographed (Fig. 3). Nuclear extracts from unstimulated cells showed no bands (lane 1), whereas stimulation led to two bands (lane 2, arrows), both of which were reduced with increasing concentrations of CsA (lanes 3-8). Band quantitation by Bio-Imager showed an $\mathrm{IC}_{50}$ of $8 \mu \mathrm{g} /$ liter (95\% CI, 5-12 $\mu \mathrm{g}$ / liter) for each band.

Characterization of the proteins and binding specificity involved in these bands was undertaken using the proteins from the stimulated group (Fig. 3, lane 2). Incubation of the nuclear extracts with antibodies to NFATC1 or NFATC2 specifically eliminated both bands, with NFATC2 treatment leading to the appearance of a new, supershifted band (Fig. 4). Also, preincubation of the proteins with nonradioactive DNA probes corresponding to the IFN- $\gamma \mathrm{P} 2$ site or the homologous $\mathrm{P} 2$ site from the human IL-4 promoter abolished the bands, whereas a mutant $\mathrm{P} 2$ probe had no effect. Thus the DNA-binding activity in stimulated PBL that was inhibited by CsA was recognized by two different anti-NFAT antibodies, and specifically bound NFAT-binding sites. The presence of two bands may represent
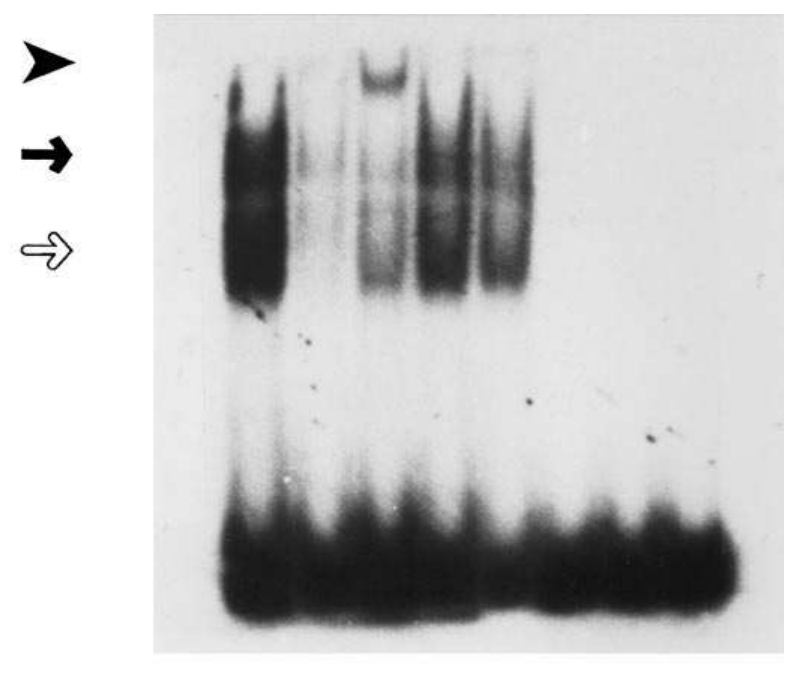

Lane

\section{$\begin{array}{llllllll}1 & 2 & 3 & 4 & 5 & 6 & 7 & 8\end{array}$}

Figure 4. Characterization of DNA-binding proteins from nuclei of stimulated PBL. Nuclear extracts of stimulated PBL (Fig. 3, lane 2) were incubated for $3 \mathrm{~h}$ at room temperature with nothing (lane 1), anti-NFATC2 polyclonal antibody (lane 2), anti-NFATC1mAb (lane 3 ), a nonspecific polyclonal antimurine control antibody (lane 4), a mutant nonradioactive P2 DNA sequence (lane 5), nonradioactive P2 DNA (lane 6), or a nonradioactive NFAT-binding sequence from the IL-4 promoter (lane 7). The mixtures were then incubated with the ${ }^{32} \mathrm{P}$-labeled DNA probe described in Fig. 3. The mixtures were then run through a $6 \%$ TBE gel, dried, and autoradiographed. Lane 8 represents the DNA probe in the absence of nuclear proteins.

the binding of NFAT alone (lower band, white arrow) or NFAT in conjunction with other proteins such as AP-1 (upper band, black arrow), as has been shown in other studies of NFAT $(10,11)$.

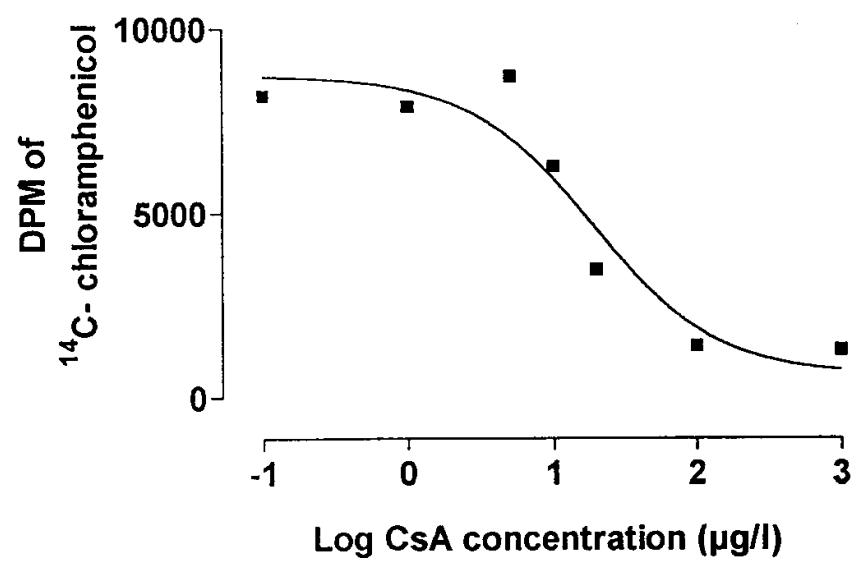

Figure 5. Effect of in vitro CsA on the induction of CAT activity in transfected PBL. PBL were exposed to $1 \%$ PHA for $3 \mathrm{~d}$, washed and suspended in medium at $20 \times 10^{6} / \mathrm{ml}$, and incubated with $80 \mu \mathrm{l} / \mathrm{ml}$ of DNA encoding a plasmid containing three P2 sites upstream of an SV-40 promoter-driven CAT gene. Electroporation was performed on aliquots of cells. The transfectants were pooled, then split for CsA treatment $(30 \mathrm{~min})$ followed by exposure to A23187 $(5 \mu \mathrm{M})$. After $48 \mathrm{~h}$, cells were harvested, and CAT activity was measured. 


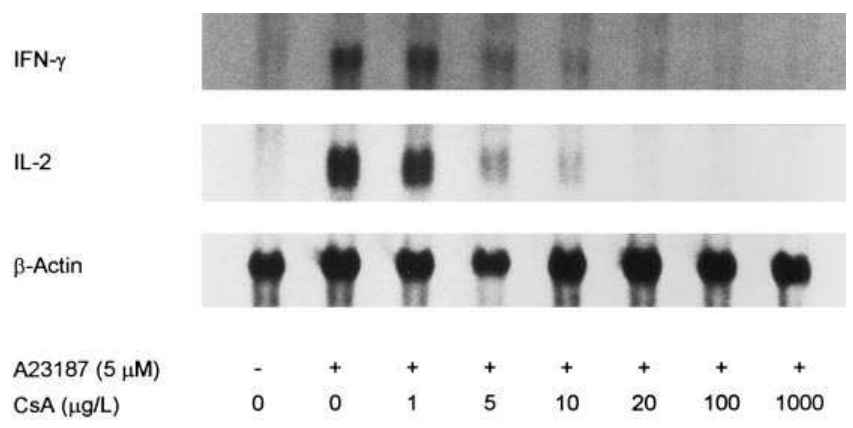

Figure 6. Effect of in vitro CsA on IFN- $\gamma$ - and IL-2 mRNA levels in stimulated PBL. After exposure to CsA (or solvent control), PBL were unstimulated or stimulated with A23187 $5 \mu \mathrm{M}$ for $1 \mathrm{~h}$, and RNA was extracted with cesium chloride, run through an agarose gel, transferred to nitrocellulose, and probed with ${ }^{32} \mathrm{P}$-labeled cDNAs for human IFN- $\gamma$, IL-2, and $\beta$-actin. The blots were then autoradiographed.

The effect of $C N$ inhibition on a transfected reporter gene with NFAT sites. To investigate the effect of $\mathrm{CN}$ inhibition on functional activity of the transcription factors activating defined NFAT promoter sites, we transfected human PBL-blasts with a plasmid encoding three $\mathrm{P} 2$ sites upstream of a CAT reporter gene (Fig. 5). The construct without the $\mathrm{P} 2$ sites was not activated by A23187 exposure, whereas the construct with the P2 sites showed a 15-fold increase in CAT activity (data not shown). CsA pretreatment led to a stepwise reduction in CAT activity, with an $\mathrm{IC}_{50}$ of $16 \mu \mathrm{g} /$ liter ( $95 \% \mathrm{CI}, 2-146 \mu \mathrm{g} /$ liter).

Effect of partial CN inhibition on induction of IFN- $\gamma-$ and $I L-2$ mRNA levels. We then studied the effect of in vitro CsA on steady state IFN- $\gamma$ - and IL-2 mRNA levels in PBL stimulated by $5 \mu \mathrm{M}$ A23187. Northern blots of PBL stimulated for $1 \mathrm{~h}$ showed induction of both IFN- $\gamma$ - and IL-2 mRNA levels that were reduced with increasing CsA concentrations (Fig. 6). Quantitation by Bio-Imager and correction for $\beta$-actin levels revealed $\mathrm{IC}_{50} \mathrm{~s}$ of $5 \mu \mathrm{g} /$ liter $(95 \% \mathrm{CI}, 4-7 \mu \mathrm{g} /$ liter) for both IFN- $\gamma$ and IL-2. Similar Northern blots and identical $\mathrm{IC}_{50} \mathrm{~S}$ were seen when PBL were stimulated for $4 \mathrm{~h}$ (data not shown), indicating that CsA inhibition of mRNA induction did not simply shift the time course of induction during the first $4 \mathrm{~h}$.

Effect of partial $C N$ inhibition on IFN- $\gamma$ secretion. We used an ELISA kit to measure IFN- $\gamma$ protein secreted by PBL stimulated by $5 \mu \mathrm{M}$ A23187 for $18 \mathrm{~h}$ (Fig. 7). In two experiments, stimulation resulted in a 10-100-fold induction in IFN- $\gamma$ in the supernatants. CsA inhibited accumulation of IFN- $\gamma$ over the same concentration range described above, with $\mathrm{IC}_{50} \mathrm{~s}$ of $7 \mu \mathrm{g} /$ liter (95\% CI, 5-9 $\mu \mathrm{g} / \mathrm{liter}$ ) in both experiments.

Effect of partial CN inhibition on proliferation and IFN- $\gamma$ production in the allogeneic $M L R$. We investigated the effect of CsA on the responses of lymphocytes stimulated by alloantigens. Responder PBL were mixed with irradiated stimulator PBL in a 6-d MLR in the absence or presence of CsA. For CN and IFN- $\gamma$ measurement, cells and supernatants, respectively, were harvested on day 6. Proliferation and IFN- $\gamma$ secretion were both induced during the MLR and, as shown in Fig. 8, all parameters were inhibited by treatment by CsA. The $\mathrm{IC}_{50} \mathrm{~s}$ were as follows: thymidine incorporation, $11 \mu \mathrm{g} /$ liter $(95 \% \mathrm{CI}$, 0-7500 $\mu \mathrm{g} /$ liter); CN activity, $8 \mu \mathrm{g} /$ liter (95\% CI, 1-60 $\mu \mathrm{g} /$ liter); and IFN- $\gamma$ accumulation, $11 \mu \mathrm{g} / \mathrm{liter}$ (95\% CI, 0-1073 $\mu \mathrm{g} / \mathrm{liter}$ ).

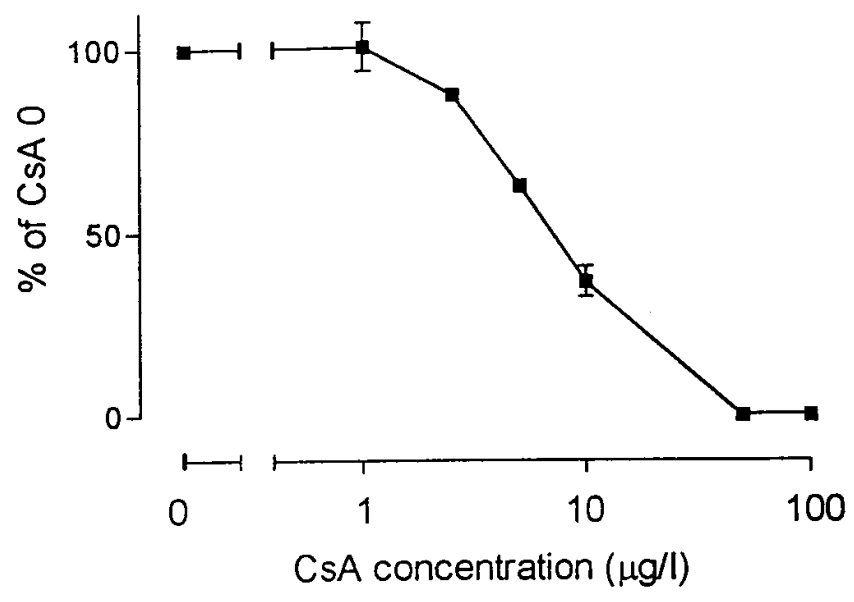

Figure 7. Effect of in vitro CsA on IFN- $\gamma$ secretion by stimulated PBL. PBL were incubated with CsA for $30 \mathrm{~min}$ at $37^{\circ} \mathrm{C}$ followed by incubation with A23187 $5 \mu \mathrm{M}$ for $18 \mathrm{~h}$, at which time IFN- $\gamma$ in the supernatants was measured by ELISA. The results represent the mean \pm SD of two experiments normalized against the stimulated CsA 0 group.

The latter values for $\mathrm{CN}$ activity and $\mathrm{FN}-\gamma$ accumulation are the same as those obtained in short-term experiments, indicating that there was no significant change in CsA effects over the 6-d experiment compared with previous short-term experiments.

\section{Discussion}

Because clinical measurements indicate that CsA treatment inhibits PBL CN activity, we studied the relationship between the degree of $\mathrm{CN}$ inhibition achieved clinically and the subsequent CsA-sensitive steps involved in cytokine gene activation and proliferation in human blood lymphocytes. The degree to which CsA inhibited each step studied-NFAT dephosphory-

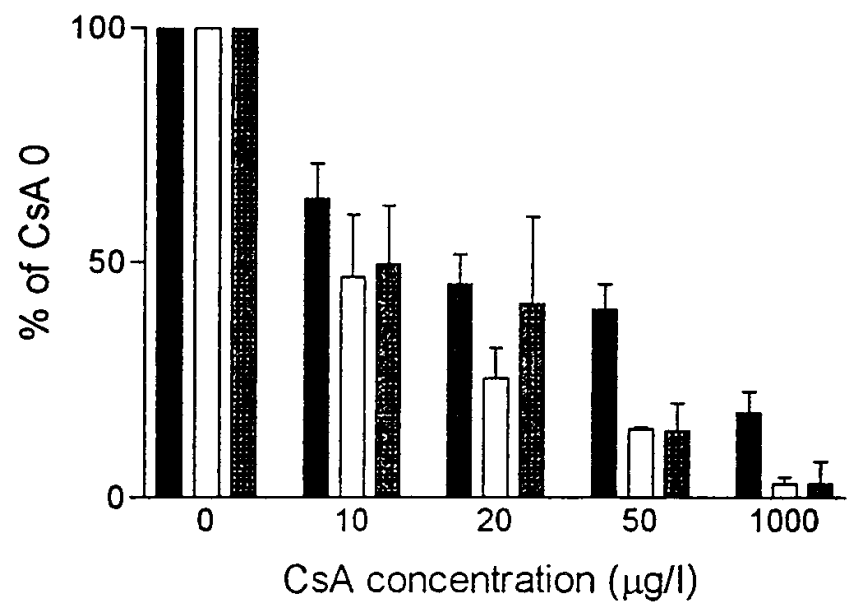

Figure 8. Effect of CsA on proliferation of PBL (black bars), CN (white bars), and IFN- $\gamma$ accumulation (stippled bars) after a $6 \mathrm{~d}$ MLR. Responder PBL were stimulated by irradiated stimulator PBL. $6 \mathrm{~d}$ later, proliferation was measured by measuring $\left[{ }^{3} \mathrm{H}\right]$ thymidine uptake. $\mathrm{CN}$ activity and IFN- $\gamma$ were measured as previously described. Results represent standardized means \pm SD of five experiments for proliferation and IFN- $\gamma$, and three experiments for $\mathrm{CN}$ activity. 
lation and translocation, appearance of NFAT-like DNAbinding activity in the nucleus, activation of a transfected reporter gene with NFAT sites in its promoter, IL-2 and IFN- $\gamma$ mRNA accumulation, IFN- $\gamma$ cytokine secretion, and cell proliferation in the MLR - was quantitatively similar to the degree to which $\mathrm{CsA}$ inhibited $\mathrm{CN}$ activity (Table I). The $\mathrm{IC}_{50} \mathrm{~s}$ for CsA inhibition of $\mathrm{CN}$ and of the downstream processes were similar, and the shapes of the concentration-inhibition curves each fit a sigmoidal dose-response kinetic model. Thus, a variety of molecular techniques each yielded a similar quantitative result for the pattern of cell response after exposure to CsA. These data agree with the previous demonstration that disruption of the CNA $\alpha$ gene, which leads to loss of $66 \%$ of total $\mathrm{CN}$ activity, is accompanied by $\mathrm{T}$ cell activation that is reduced but not eliminated (24). These data support the hypothesis that $\mathrm{CN}$ is not only essential but is rate-limiting for many activities of PBL or T cells.

The use of freshly isolated human cells may be important in establishing quantitative relationships between molecular events and may help avoid the potentially misleading results that can occur with the use of cell lines and additional CsAinsensitive stimuli such as phorbol esters. In T cell lines, intracellular signaling often differs from that observed in primary, freshly isolated, nonmalignant $\mathrm{T}$ cells. In particular, some $\mathrm{T}$ cell lines require a second chemical signal in order to become activated (37). In contrast, fresh PBL are activated by calcium ionophores alone, or by anti-T cell receptor antibodies (reference 37, and data not shown), and the addition of agents such as PMA is unnecessary. PMA recruits other pathways and may change the sensitivity of the activated cells to CsA. Furthermore, some T cell lines fail to express lymphocyte-specific cytokines such as IFN- $\gamma$ (37), perhaps due to selection against the antiproliferative effects of IFN- $\gamma$. For these studies, we chose to focus on the T/natural killer cell-specific cytokine IFN- $\gamma$ because this allowed us to use heterogeneous PBL preparations that have undergone minimal manipulation, and because purification of $\mathrm{T}$ cells often produced limiting cell numbers. Moreover, the MLR experiments indicated a similar relationship between $\mathrm{CN}$ inhibition and lymphocyte activation when the cells were stimulated through normal antigen recognition molecules, over much longer time intervals.

In addition to the quantitative effects $\mathrm{CN}$ inhibition has on

Table I. Summary of $I C_{50}$ s of CsA Effect on the Calcium-dependent Events Involved in Cytokine Gene Activation and Lymphocyte Proliferation

\begin{tabular}{lcc}
\hline & $\begin{array}{c}\text { Mean } \mathrm{IC}_{50} \\
\mu \mathrm{g} / \mathrm{liter}\end{array}$ & $\begin{array}{c}\text { Sigmoidal } \\
\text { dose-response curve fit }\end{array}$ \\
\hline & $(95 \% \mathrm{CI})$ & $r^{2}$ \\
CN activity & $10(8-14)$ & 0.9995 \\
NFATC2 activation (Western blot) & $20(15-26)$ & 0.9964 \\
DNA binding (EMSA) & $8(5-12)$ & 0.9958 \\
Promoter activation (transfection) & $19(4-92)$ & 0.9186 \\
mRNA induction - IFN- $\gamma$ & $5(4-7)$ & 0.9974 \\
& $5(4-7)$ & 0.9861 \\
IFN- $\gamma$ secretion - IL-2 & $7(5-9)$ & 0.9995 \\
Proliferation (6-d MLR) & $11(0-7500)$ & 0.9977 \\
CN activity (6-d MLR) & $8(1-60)$ & 0.9993 \\
IFN- $\gamma$ secretion (6-d MLR) & $11(0-1073)$ & 0.9975 \\
& & \\
\hline
\end{tabular}

$\mathrm{T}$ cell effector activities in vivo (e.g., cytokine production), there may also be qualitative effects. These data that $\mathrm{CN}$ inhibition in vitro is rate-limiting for IFN- $\gamma$ secretion and lymphocyte proliferation after antigen-specific stimulation in an MLR are consistent with our previous mouse results showing that the degree of in vivo $\mathrm{CN}$ inhibition correlated with the degree of inhibition of IFN- $\gamma$ production and $\mathrm{MHC}$ induction in CsAfed mice rejecting an allogeneic tumor (29). However, activation of some leukocyte activities such as TGF- $\beta$ and IL-10 is CsA-resistant. Thus, cellular and humoral immune responses might be deviated by imbalances between the CsA-sensitive and CsA-resistant activities, producing qualitative shifts in the immune response. Whether this could shift the response toward mechanisms promoting anergy is unknown, but possible. $\mathrm{T}$ cell response can deviate toward different, mutually exclusive patterns of cytokine and cell surface molecule expression $(38,39)$, possibly many different patterns $(39,40)$, which are themselves influenced by the cytokines being produced in the environment. Therefore, it is possible that due to the relative resistance of some activation genes, partial $\mathrm{CN}$ inhibition in a population of CsA-treated cells may alter the ratio between CsA-sensitive and CsA-resistant cytokines and thus shift the character of the response as well as reducing its magnitude.

Thus, an array of clinical, murine in vivo, and molecular data support the hypothesis that $\mathrm{CN}$ activity is not just essential but is rate-limiting for the activation of a number of lymphocyte genes. The demonstration of an enzyme activity quantitatively rate-limiting for lymphocyte activation must be distinguished from the evidence that it is essential. Genetic immunodeficiency syndromes in humans have provided definitive evidence that the $\gamma_{c}$ receptor chain (41) and the tyrosine kinases JAK3 and ZAP-70 (42-45) are essential for lymphocyte response and function. The ability to breed mice lacking specific genes has allowed the study of other signal transduction molecules believed to be important in lymphocyte activation, including Ras, protein kinase C, and CD28. Knocking out each gene in these pathways has been associated with effects on lymphocyte behavior (46-48). The CD28 knockout mice, despite significant defects in lymphocyte function in vitro (49, 50 ), were still able to reject allogeneic skin grafts (51). However, the observations based on natural and induced mutations do not indicate whether these molecules function qualitatively as on-off switches, or whether there is a quantitative effect. It is possible that one or more other steps within the CN-dependent activation pathway may also be rate-limiting, and that by limiting amounts of, for example, ZAP-70 or NFAT, a parallel reduction in lymphocyte activation might be observed. Mice lacking the CNA $\alpha$ gene showed evidence for both immunosuppression and immunoreactivity (24). Despite lacking the $\mathrm{CNA} \alpha$, these animals retained $34 \%$ of normal $\mathrm{CN}$ activity because of other CNA isoforms. Thus, these animals have a similar degree of $\mathrm{CN}$ inhibition as that seen in transplant patients, and their immune systems behave in a similar fashion. Finally, Shibasaki et al. have demonstrated a vigorous kinase activity that resulted in the rephosphorylation, and therefore the inactivation and nuclear export, of NFATC3 (originally called NFAT-4) (52), suggesting that NFAT activation requires continuous $\mathrm{CN}$ activity. Under these circumstances, increments in $\mathrm{CN}$ activity would be expected to lead to increments in NFAT activation, promoter binding and activation, etc.

Coupled with the previous data that $\mathrm{CN}$ is only partially inhibited in CsA-treated patients, these results help explain the 
clinical characteristics of CsA, particularly the basis for its safety and efficacy. CsA produces incomplete $\mathrm{CN}$ inhibition in PBL of CsA-treated patients $(25,26)$. Its safety, as shown by the low incidence of opportunistic infections (53), is due to the fact that some $\mathrm{CN}$ activity and thus lymphocyte responsiveness is preserved, permitting specific immune responses against infectious agents and preventing immunodeficiency. Thus CsAtreated patients can reject allografts (54), express abundant $\mathrm{T}$ cell cytokines (55), and be immunized against exogenous antigens (56). The effectiveness of CsA, evident by the reduction in allograft rejection rates (57) and the successful treatment of some autoimmune disorders (58), is due to the reduction in $\mathrm{CN}$ activity and its subsequent quantitative (and qualitative?) effect on immune responses. Further study of the CNA $\alpha$ gene knockout mice, with their $66 \%$ reduction in $\mathrm{CN}$ activity, will be helpful in defining the impact of partial $\mathrm{CN}$ inhibition on in vivo immune responses. In addition, more detailed in vivo animal studies investigating the entire dosage range of CsA will provide additional data regarding the consequences of $\mathrm{CN}$ inhibition on the function of an intact immune system. We propose that the immunosuppressive effect of CsA, and presumably also FK506, is due to its inhibition of $\mathrm{CN}$ activity, which is rate-limiting for lymphocyte activation. Recently, studies of the effect of the immunosuppressive drug mycophenolate mofetil have suggested that it too only produces partial inhibition of its target enzyme inosine monophosphate dehydrogenase (59). Thus, partial inhibition of rate-limiting enzymes may be a general theme in immunosuppressive drugs used for maintenance therapy, where the immune response must be blunted for control of disease activity but retained for longterm host defense.

\section{Acknowledgments}

We wish to thank Drs. Anjana Rao and Gerald Crabtree for materials and helpful discussion, Mrs. Janet Enns for technical assistance, and Ms. Pam Publicover for secretarial assistance.

This research is supported by the Kidney Foundation of Canada, the Alberta Heritage Foundation for Medical Research, the Medical Research Council of Canada, the Royal Canadian Legion, and Novartis Pharmaceuticals Canada Inc.

\section{References}

1. Hsu, V.L., and I.M. Armitage. 1992. Solution structure of cyclosporin A and a nonimmunosuppressive analog bound to fully deuterated cyclophilin. Biochemistry. 31:12778-12784.

2. Pflugl, G., J. Kallen, T. Schirmer, J.N. Jansonius, M.G.M. Zurini, and M.D. Walkinshaw. 1993. X-ray structure of a decameric cyclophilin-cyclosporin crystal complex. Nature (Lond.). 361:91-94.

3. Thériault, Y., T.M. Logan, R. Meadows, L. Yu, E.T. Olejniczak, T.F. Holzman, R.L. Simmer, and S.W. Fesik. 1993. Solution structure of the cyclosporine A/cyclophilin complex by NMR. Nature (Lond.). 361:88-91.

4. Clipstone, N.A., and G.R. Crabtree. 1992. Identification of calcineurin as a key signalling enzyme in T-lymphocyte activation. Nature (Lond.). 357:695697.

5. Foor, F., S.A. Parent, N. Morin, A.M. Dahl, N. Ramadan, G. Chrebet, K.A. Bostian, and J.B. Nielsen. 1992. Calcineurin mediates inhibition by FK506 and cyclosporin of recovery from $\alpha$-factor arrest in yeast. Nature (Lond.). 360: 682-684

6. Schreiber, S.L., and G.R. Crabtree. 1992. The mechanism of action of cyclosporin A and FK506. Immunol. Today. 13:136-142.

7. Harding, M.W., A. Galat, D.E. Uehling, and S.L. Schreiber. 1989. A receptor for the immunosuppressant FK506 is a cis-trans peptidyl-prolyl isomerase. Nature (Lond.). 341:758-760.

8. Kay, J.E., C.R. Benzie, M.R. Goodier, C.J. Wick, and S.E.A. Doe. 1989. Inhibition of T-lymphocyte activation by the immunosuppressive drug FK-506. Immunology. 67:473-477.
9. Shaw, K.T.-Y., A.M. Ho, A. Raghavan, J. Kim, J. Jain, J. Park, S. Sharma, A. Rao, and P.G. Hogan. 1995. Immunosuppressive drugs prevent a rapid dephosphorylation of transcription factor NFAT1 in stimulated immune cells. Proc. Natl. Acad. Sci. USA. 92:11205-11209.

10. McCaffrey, P.G., C. Luo, T.K. Kerppola, J. Jain, T.M. Badalian, A.M Ho, E. Burgeon, W.S. Lane, J.N. Lambert, T. Curran, et al. 1993. Isolation of the cyclosporin-sensitive T cell transcription factor NFATp. Science (Wash. DC). 262:750-754

11. Jain, J., P.G. McCaffrey, Z. Miner, T.K. Kerppola, J.N. Lambert, G.L. Verdine, T. Curran, and A. Rao. 1993. The T-cell transcription factor NFAT is $_{\mathrm{p}}$ a substrate for calcineurin and interacts with Fos and Jun. Nature (Lond.). 365: 352-355.

12. Northrop, J.P., S.N. Ho, L. Chen, D.J. Thomas, L.A. Timmerman, G.P. Nolan, A. Admon, and G.R. Crabtree. 1994. NF-AT components define a family of transcription factors targeted in T-cell activation. Nature (Lond.). 369: 497-502.

13. Ullman, K.S., J.P. Northrop, A. Admon, and G.R. Crabtree. 1993. Jun family members are controlled by a calcium-regulated, cyclosporin A-sensitive signaling pathway in activated T lymphocytes. Genes Dev. 7:188-196.

14. Rincón, M., and R.A. Flavell. 1994. AP-1 transcriptional activity requires both $\mathrm{T}$-cell receptor-mediated and co-stimulatory signals in primary $\mathrm{T}$ lymphocytes. EMBO (Eur. Mol. Biol. Organ.) J. 13:4370-4381.

15. Su, B., E. Jacinto, M. Hibi, T. Kallunki, M. Karin, and Y. Ben-Neriah. 1994. JNK is involved in signal integration during costimulation of T lymphocytes. Cell. 77:727-736.

16. Kanno, T., and U. Siebenlist. 1996. Activation of nuclear factor-кB via T cell receptor requires a Raf kinase and $\mathrm{Ca}^{2+}$ influx. Functional synergy between Raf and calcineurin. J. Immunol. 157:5277-5283.

17. Frantz, B., E.C. Nordby, G. Bren, N. Steffan, C.V. Paya, R.L. Kincaid, M.J. Tocci, S.J. O'Keefe, and E.A. O'Neill. 1994. Calcineurin acts in synergy with PMA to inactivate IкB/MAD3, an inhibitor of NF-кB. EMBO (Eur. Mol. Biol. Organ.) J. 13:861-870.

18. Nolan, G.P. 1994. NF-AT-AP-1 and Rel-bZIP: hybrid vigor and binding under the influence. Cell. 77:795-798.

19. Woodrow, M., N.A. Clipstone, and D. Cantrell. 1993. p21 $1^{\text {ras }}$ and calcineurin synergize to regulate the nuclear factor of activated T cells. J. Exp. Med. 178:1517-1522.

20. Rao, A. 1995. NFATp, a cyclosplorin-sensitive transcription factor implicated in cytokine gene induction. J. Leukocyte Biol. 57:536-542.

21. Fuleihan, R., N. Ramesh, A. Horner, D. Ahern, P.J. Belshaw, D.G. Alberg, I. Stamenkovic, W. Harmon, and R.S. Geha. 1994. Cyclosporin A inhibits CD40 ligand expression in T lymphocytes. J. Clin. Invest. 93:1315-1320.

22. O'Keefe, S.J., J. Tamura, R.L. Kincaid, M.J. Tocci, and E.A. O'Neill. 1992. FK-506 and CsA-sensitive activation of the interleukin-2 promoter by calcineurin. Nature (Lond.). 357:692-694.

23. Liu, J., M.W. Albers, T.J. Wandless, S. Luan, D.G. Alberg, P.J. Belshaw, P. Cohen, C. MacKintosh, C.B. Kless, and S.L. Schreiber. 1992. Inhibition of T cell signaling by immunophilin-ligand complexes correlates with loss of calcineurin phosphatase activity. Biochemistry. 31:3896-3901.

24. Zhang, W., G. Zimmer, J. Chen, D. Ladd, E. Li, F.W. Alt, G. Wiederrecht, J. Cryan, E.A. O’Neill, C.E. Seidman, et al. 1996. T cell responses in calcineurin A-deficient mice. J. Exp. Med. 183:413-420.

25. Batiuk, T.D., F. Pazderka, and P.F. Halloran. 1995. Calcineurin activity is only partially inhibited in leukocytes of cyclosporine-treated patients. Transplantation (Baltimore). 59:1400-1404.

26. Pai, S.Y., D.A. Fruman, T. Leong, D. Neuberg, T.G. Rosano, C. McGarigle, J.H. Antin, and B.E. Bierer. 1994. Inhibition of calcineurin phosphatase activity in adult bone marrow transplant patients treated with cyclosporine A. Blood. 84:3974-3979.

27. Batiuk, T.D., F. Pazderka, J. Enns, L. DeCastro, and P.F. Halloran. 1995. Cyclosporine inhibition of calcineurin activity in human leukocytes in vivo is rapidly reversible. J. Clin. Invest. 96:1254-1260.

28. Quien, R.M., B.A. Kaiser, S.P. Dunn, A. Kulinsky, M. Polinsky, H.J. Baluarte, T.D. Batiuk, and P.F. Halloran. 1997. Calcineurin activity in children with renal transplants receiving cyclosporine. Transplantation (Baltimore). In press.

29. Batiuk, T.D., J. Urmson, D. Vincent, R.W. Yatscoff, and P.F. Halloran. 1996. Quantitating immunosuppression: estimating the $\mathrm{IC}_{50}$ for in vivo cyclosporine in mouse. Transplantation (Baltimore). 61:1618-1624.

30. Fruman, D.A., C.B. Klee, B.E. Bierer, and S.J. Burakoff. 1992. Calcineurin phosphatase activity in T lymphocytes is inhibited by FK506 and cyclosporin A. Proc. Natl. Acad. Sci. USA. 89:3686-3690.

31. Batiuk, T.D., F. Pazderka, J. Enns, L. DeCastro, and P.F. Halloran. 1996. Cyclosporine inhibition of leukocyte calcineurin is much less in whole blood than in culture medium. Transplantation (Baltimore). 61:158-161.

32. Kaye, R.E., D.A. Fruman, B.E. Bierer, M.W. Albers, L.D. Zydowsky, S.I. Ho, Y.J. Jin, M.C. Castells, S.L. Schreiber, C.T. Walsh, et al. 1992. Effects of cyclosporin A and $\mathrm{FK} 506$ on $\mathrm{Fc}_{\gamma}$ receptor type I-initiated increases in cytokine mRNA in mouse bone marrow-derived progenitor mast cells: resistance to FK506 is associated with a deficiency in FK506-binding protein FKBP12. Proc. Natl. Acad. Sci. USA. 89:8542-8546.

33. Campbell, P.M., J. Pimm, V. Ramassar, and P.F. Halloran. 1996. Identi- 
fication of a calcium inducible, cyclosporine-sensitive element in the IFN- $\gamma$ promoter that is a potential NFAT binding site. Transplantation (Baltimore). 61: 933-939.

33a. Abe, E., R. De Waal Malefyt, I. Matsuda, K. Arai, and N. Arai. 1992. An 11-base-pair DNA sequence motif apparently unique to the human interleukin 4 gene confers responsiveness to T-cell activation signals. Proc. Natl. Acad. Sci. USA. 89:2864-2868.

34. Maniatis, T., E.F. Fritsch, and J. Sambrook. 1982. Molecular Cloning: A Laboratory Manual. Cold Spring Harbor Laboratory, Cold Spring Harbor, N.Y. 196 pp.

35. Chomczynski, P., and N. Sacchi. 1987. Single-step method of RNA isolation by acid guanidinium thiocyanate-phenol-chloroform extraction. Anal. Biochem. 162:156-159.

36. Thomas, P.S. 1980. Hybridization of denatured RNA and small DNA fragments transferred to nitrocellulose. Proc. Natl. Acad. Sci. USA. 77:52015205.

37. Pazderka, F., J. Enns, T.D. Batiuk, and P.F. Halloran. 1996. The functional consequences of partial calcineurin inhibition in human peripheral blood mononuclear leucocytes. Transpl. Immunol. 4:23-31.

38. Mosmann, T.R., and R.L. Coffman. 1989. Th1 and Th2 cells: different patterns of lymphokine secretion lead to different functional properties. Ann. Rev. Immunol. 10:145-173.

39. Mosmann, T.R., and S. Sad. 1996. The expanding universe of T-cell subsets: Th1, Th2 and more. Immunol. Today. 17:138-146.

40. Kelso, A. 1995. Th1 and Th2 subsets: paradigms lost? Immunol. Today. 16:374-379.

41. Voss, S.D., R. Hong, and P.M. Sondel. 1994. Severe combined immunodeficiency, interleukin-2 (IL-2), and the IL-2 receptor: experiments of nature continue to point the way. Blood. 83:626-635.

42. Macchi, P., A. Villa, S. Gillani, M.G. Sacco, A. Frattini, F. Porta, A.G. Ugazio, J.A. Johnston, F. Candotti, J.J. O'Shea, et al. 1995. Mutations of Jak-3 gene in patients with autosomal severe combined immune deficiency (SCID). Nature (Lond.). 377:65-68.

43. Russell, S.M., N. Tayebi, H. Nakajima, M.C. Riedy, J.L. Roberts, M.J. Aman, T.-S. Migone, M. Noguchi, M.L. Markert, R.H. Buckley, et al. 1995. Mutation of Jak3 in a patient with SCID: essential role of Jak3 in lymphoid development. Science (Wash. DC). 270:797-800.

44. Elder, M.E., D. Lin, J. Clever, A.C. Chan, T.J. Hope, A. Weiss, and T.G. Parslow. 1994. Human severe combined immunodeficiency due to a defect in ZAP-70, a T cell tyrosine kinase. Science (Wash. DC). 264:1596-1599.

45. Chan, A.C., T.A. Kadlecek, M.E. Elder, A.H. Filipovich, W.L. Kuo, M. Iwashima, T.G. Parslow, and A. Weiss. 1994. ZAP-70 deficiency in an autosomal recessive form of severe combined immunodeficiency. Science (Wash. DC). 264:1599-1601.
46. Leitges, M., C. Schmedt, R. Guinamard, J. Davoust, S. Schaal, S. Stabel, and A. Tarakhovsky. 1996. Immunodeficiency in protein kinase C $\beta$-deficient mice. Science (Wash. DC). 273:788-791.

47. Henkemeyer, M., D.J. Rossi, D.P. Holmyard, M.C. Puri, G. Mbamalu, K. Harpai, T.S. Shih, T. Jacks, and T. Pawson. 1995. Vascular system defect and neuronal apoptosis in mice lacking Ras GTPase-activating protein. Nature (Lond.). 377:695-701.

48. Umanoff, H., W. Edelmann, A. Pellicer, and R. Kucherlapati. 1995. The murine N-ras gene is not essential for growth and development. Proc. Natl. Acad. Sci. USA. 92:1709-1713.

49. Shahinian, A., K. Pfeffer, K.P. Lee, T.M. Kündig, K. Kishihara, A Wakeham, K. Kawai, P.S. Ohashi, C.B. Thompson, and T.W. Mak. 1993. Differential T cell costimulatory requirements in CD28-deficient mice. Science (Wash. DC). 261:609-612.

50. Green, J.M., P.J. Noel, A.I. Sperling, T.L. Walunas, G.S. Gray, J.A Bluestone, and C.B. Thompson. 1994. Absence of B7-dependent responses in CD28-deficient mice. Immunity. 1:501-508.

51. Kawai, K., A. Shahinian, T.W. Mak, and P.S. Ohashi. 1996. Skin allograft rejection in CD28-deficient mice. Transplantation (Baltimore). 61:352355 .

52. Shibasaki, F., E.R. Price, D. Milan, and F. McKeon. 1996. Role of kinases and the phosphatase calcineurin in the nuclear shuttling of transcription factor NF-AT4. Nature (Lond.). 382:370-373.

53. von Graffenried, B., and W.B. Harrison. 1993. Side effects (with emphasis on renal dysfunction) and recommendations for use. In Ciclosporin in Autoimmune Diseases. R. Schindler, editor. Springer-Verlag, Berlin/Heidelberg. $60-73$.

54. Koyama, H., and J.M. Cecka. 1992. Rejection episodes. In Clinical Transplants. P.I. Terasaki and J.M. Cecka, editors. UCLA Tissue Typing Laboratory, Los Angeles. 391-404.

55. Halloran, P.F., P. Autenried, and A. Wadgymar. 1986. Regulation of HLA antigen expression in human kidney. Clinics in Immunology and Allergy. 6:411-435.

56. Palestine, A.G., F. Roberge, B.L. Charous, H.C. Lane, A.S. Fauci, and R.B. Nussenblatt. 1985. The effect of cyclosporine on immunization with tetanus and keyhole limpet hemocyanin (KLH) in humans. J. Clin. Immunol. 5: $115-121$.

57. Kahan, B.D. 1989. Cyclosporine. N. Engl. J. Med. 321:1725-1738.

58. Fathman, C.G., and B.D. Myers. 1992. Cyclosporine therapy for autoimmune disease. N. Engl. J. Med. 326:1693-1695.

59. Langman, L.J., D.F. LeGatt, P.F. Halloran, and R.W. Yatscoff. 1996. Pharmacodynamic assessment of mycophenolic acid-induced immunosuppression in renal transplant recipients. Transplantation (Baltimore). 62:666-672. 